\title{
Az idült májbetegségek progressziójához vezető folyamatok
}

\author{
Egresi Anna dr. ${ }^{1}$ - Lengyel Gabriella dr. ${ }^{1}$ - Somogyi Anikó dr. ${ }^{1}$ \\ Blázovics Anna dr. ${ }^{2}$ - Hagymási Krisztina dr. ${ }^{1}$ \\ ${ }^{1}$ Semmelweis Egyetem, Általános Orvostudományi Kar, II. Belgyógyászati Klinika, Budapest \\ ${ }^{2}$ Semmelweis Egyetem, Gyógyszerésztudományi Kar, Farmakognóziai Intézet, Budapest
}

\begin{abstract}
Különböző károsító hatások miatt (vírusok, anyagcserezavarok, táplálkozási tényezők, toxikus ártalmak, autoimmun folyamatok) kóros májmúködés lép fel, amely a máj elzsírosodásához és kötőszövetes átépüléséhez vezet. A progreszszió folyamata összetett, több útvonalon megy végbe, számos tényező befolyásolja. A szerzők összefoglaló közleményükben áttekintik a krónikus májbetegségek progressziójában részt vevő tényezóket. Bemutatják a sejtek szerepét, az általuk termelt foóbb citokineket és gyulladásos mediátorokat, valamint az intestinalis bélflóra kapcsolatát a betegséggel. Kitérnek az oxidatív stressz, a mitokondriális diszfunkció és a sejthalál kórlefolyásban betöltött szerepére. Ismertetik az inzulinrezisztencia és a mikroelemek (vas, réz) kapcsolatát a májkárosodással. Összefoglalják a progreszszió hátterében álló genetikai és epigenetikai vonatkozásokat is. Az új kezelési lehetőségek felismerése, a kezelés hatékonyságának megítélése vagy a májátültetés időpontjának megválasztása, sikeressége függhet a kórlefolyás pontosabb megismerésétől. Orv. Hetil., 2016, 157(8), 290-297.
\end{abstract}

Kulcsszavak: májelzsírosodás, progresszió, hepatitis, fibrosis, oxidatív stressz, mitokondriális diszfunkció, csillagsejtek, intestinalis bélflóra

\section{Various pathways leading to the progression of chronic liver diseases}

As the result of various effects (viruses, metabolic diseases, nutritional factors, toxic agents, autoimmune processes) abnormal liver function, liver steatosis and connective tissue remodeling may develop. Progression of this process is complex including various pathways and a number of factors. The authors summarize the factors involved in the progression of chronic liver disease. They describe the role of cells and the produced inflammatory mediators and cytokines, as well as the relationship between the disease and the intestinal flora. They emphasize the role of oxidative stress, mitochondrial dysfunction and cell death in disease progression. Insulin resistance and micro-elements (iron, copper) in relation to liver damage are also discussed, and genetic and epigenetic aspects underlying disease progression are summarized. Discovery of novel treatment options, assessment of the effectiveness of treatment, as well as the success and proper timing of liver transplantation may depend on a better understanding of the process of disease progression.

Keywords: liver steatosis, progression, hepatitis, fibrosis, oxidative stress, mitochondrial dysfunction, stellate cells, intestinal flora

Egresi, A., Lengyel, G., Somogyi, A., Blázovics, A., Hagymási, K. [Various pathways leading to the progression of chronic liver diseases]. Orv. Hetil., 2016, 157(8), 290-297.

(Beérkezett: 2015. december 12.; elfogadva: 2016. január 7.)

\section{Rövidítések}

AFLD = alkoholos zsírmájbetegség; ATP = adenozin-5' - trifoszfát; CCR 5 = kemokinligand-5; CRP = C-reaktív protein; $\mathrm{Cu}=$ réz; $\mathrm{DM}=$ diabetes mellitus; $\mathrm{DNS}=$ deoxiribonuklein sav; $\mathrm{ECM}=$ extracelluláris mátrix; ETC = elektrontranszportlánc; $\mathrm{FXR}=$ farnezoid $\mathrm{X}$-receptor; $\mathrm{HBV}=$ hepatitis $\mathrm{B}$-vírus;
$\mathrm{HCV}=$ hepatitis C-vírus; HSC = (hepatic stellate cell $)$ csillagsejt; $\mathrm{GSH}=$ glutation; $\mathrm{IL}=$ interleukin; $\mathrm{LXR}=$ máj X-receptor; MDA $=$ malondialhid; $\mathrm{MMP}=$ mátrixmetalloproteináz; NAFLD $=$ nem alkoholos zsírmáj; $\mathrm{NASH}=$ nem alkoholos steatohepatitis; PPAR = peroxiszómaproliferátor aktiválta receptor; $\mathrm{PXR}$ = pregnán $\mathrm{X}$-receptor; RES = reticuloendothelialis 
rendszer; RNS = ribonukleinsav; ROS = reaktívoxigén-gyökök; SAM = S-adenozil-metionin; SOD = szuperoxid dizmutáz; SREBP-lc $=$ sterol regulatory element binding protein- $\mathrm{l} c$; TGF- $\beta=$ transzformáló növekedési faktor $-\beta$; TIMP $=$ mátrixmetalloproteináz szöveti gátló; TLR = toll-like receptor; TNF- $\alpha=$ tumornekrózis-faktor- $\alpha$; TNFRl $=$ tumornekrózisfaktor receptor $1 ; \mathrm{Zn}=$ cink

A kóros májmúködés különböző idült behatások (vírusfertőzések, autoimmun folyamatok, toxikus ártalmak, cholestaticus és anyagcsere-betegségek) közös patológiai következménye (1. ábra) [1]. A gyulladás, elzsírosodás következtében sejtkárosodás, majd kötőszövetes átépülés jön létre. A különböző károsító hatások során kóros lipidanyagcsere és glükózháztartás is kialakul. A májsejtekben lévő mitokondriumok alkalmazkodnak a megváltozott lipidösszetételhez, amelynek következtében a $\beta$-oxidáció és az elektrontranszportlánc (ETC) enzimatikus aktivitása megnövekszik. Ez reaktívoxigén-gyökök (ROS) felszabadulásához vezet [2].

Több sejtes elem mellett a májban lévő csillagsejtek (hepatic stellate cells - HSC) játsszák a legnagyobb szerepet a kötőszövetes átépülés folyamatában. Májkárosodás során ezek a sejtek myofibroblastokká differenciálódnak, amelyek majdnem az összes kötőszöveti elem szintézisére (kollagén, elasztin, szerkezeti glikoprotein, proteoglikán, hialuronsav) képesek, ezzel megteremtve a máj kötőszövetes átépülésének alapját [3]. A HSC-k aktiválódását és myofibroblastokká történő átalakulását sejtes kölcsönhatások, valamint növekedési faktorok, kemokinek és reaktívoxigén-gyökök által közvetített parakrin stimuláció irányítják $[3,4]$.

Az extracelluláris mátrix progresszív felszaporodásával és megnövekedett átépülésével jellemezhető májfibrosis miatt a máj szerkezete megváltozik. Kezelés nélkül a fibrosis májcirrhosishoz, végül májelégtelenséghez és következményesen halálhoz vezet. A progresszió hátterében sejtes és molekuláris mechanizmusok is állnak [5].

A szerzők összefoglaló közleményükben ismertetik a különböző kórokú, idült májbetegségek progressziójának hátterében álló, a patomechanizmusban szerepet játszó sejtes és molekuláris folyamatokat (2. ábra) [6].

\section{Sejtes elemek szerepe}

\section{Csillagsejtek}

A májlobulus parenchymalis (hepatocyták) és nem parenchymalis sejtcsoportokból áll. A teljes májtérfogat 80\%-át a májsejtek alkotják, amelyek a májmúködést biztosítják. A sinusoid kompartmentben található nem parenchymalis sejtcsoport a májtérfogat $6,5 \%$-át foglalja el. A sinusoidok falát három sejtféleség alkotja: a sinusoidalis endothelsejtek, a Kupffer-sejtek és a csillagsejtek, vagy más néven Ito-sejtek, perisinusoidalis sejtek, A-vitaminban gazdag sejtek. Májkárosodás során a nyugvó csil- lagsejtek myofibroblastszerü sejtekké differenciálódnak, amelyek kulcsszerepet játszanak a kötőszövetes átépülés elindításában és fenntartásában [7]. Számos kötőszöveti elem termelésére képesek, például kollagének, elasztin, szerkezeti glikoproteinek, proteoglikán, hialuronsav szintézisében játszanak szerepet $[3,8]$.

A myofibroblastok nemcsak a kötőszöveti elemek széles spektrumát képesek termelni. hanem fibrogenetikus

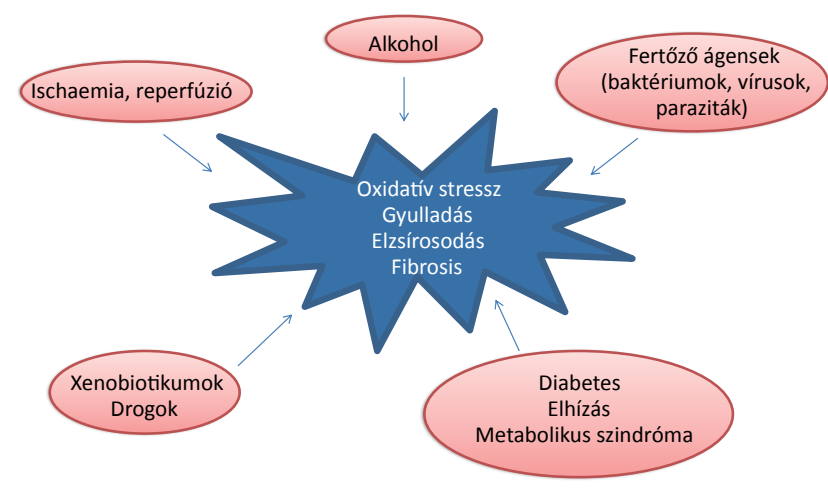

1. ábra | A krónikus májkárosodás különböző okai [1]

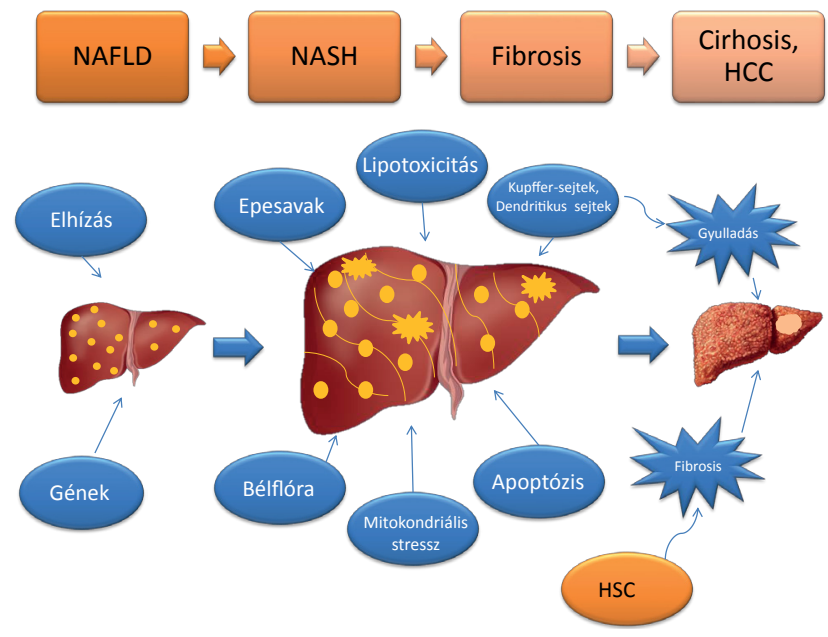

2. ábra $\quad$ A nem alkoholos zsírmáj progressziójában szerepet játszó tényezők [6]

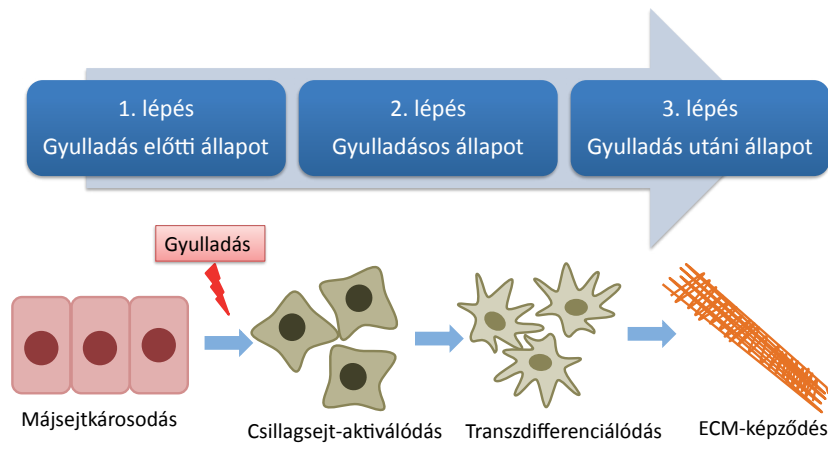

3. ábra Gyulladásos aktivitás következtében létrejövő extracelluláris mátrix képződése 
citokineket (TGF- $\alpha$, TGF- $\beta$ ) és enzimeket is szintetizálnak, például a mátrixmetalloproteinázokat (MMP) és azok szöveti gátlóit (TIMP), amelyek a kollagének katabolizmusát szabályozzák $[7,8]$. Gyulladásos sejtek vándorlását elindító kemokinek termelésével a gyulladásos választ felerősítik. A sejtfelszíni ICAM-1- (intercelluláris adhéziós molekula-1) és VCAM-1-(vascularis sejt adhéziós molekula-1) kifejeződés (expresszió) a lymphocyták vándorlását és adhézióját segíti elő (3. ábra) [5].

\section{Portalis fibroblastok és fibrocyták}

A mesenchymalis eredetú portalis fibroblastok myofibroblastokká differenciálódnak elsősorban cholestaticus májkárosodások során. Bár biológiai hasonlóságot mutatnak az aktivált csillagsejtekkel, de genetikai profiljuk és jelátviteli válaszuk eltér [5].

A fibrocyták a haematopoeticus őssejtekból erednek és képesek myofibroblastokká differenciálódni. Szöveti károsodás során proliferálnak és a sérült szervbe vándorolnak, ahol olyan növekedési faktorokat termelnek, amelyek az extracelluláris mátrix lerakódását beindítják [5].

\section{Dendritikus sejtek}

A májban lévő dendritikus sejtek egy heterogén csoportot képeznek a máj sinusoidalis antigén-bemutató sejtjei között. Főleg a periportalis és a pericentrális térben helyezkednek el, és a nem parenchymalis sejtek kevesebb, mint 1\%-át alkotják. Tagjai a máj reticuloendothelialis rendszerének, amely a sinusoidalis endothelsejteket és a Kupffer-sejteket is magában foglalja [6].

A dendritikus sejtek és a fibrogenesis között kapcsolatot feltételeznek. Rahman és Aloman megállapítása szerint a dendritikus sejtek szabályozzák a fibrosis létrejöttében szerepet játszó sejtek (természetes ölősejtek és CD8+ sejtek) számát és aktivitását [6].

\section{Intestinalis bélflóra: portalis endotoxinaemia}

A gastrointestinalis rendszerben lévő mikrobák szimbiózisban élnek a gazdaszervezettel. Kapcsolatban állnak az emésztéssel és az anyagcserével. Az elhízásban, a metabolikus szindrómában és a nem alkoholos zsírmájbetegségben betöltött szerepük ismert. Az intestinalis bélflóra progressziót befolyásoló hatását intenzíven kutatják [9].

A sovány és az elhízott egyének mikrobiális flórája eltéró, amely mögött táplálkozási tényezők állhatnak. Allogén intestinalis bélflóra átültetése sovány donorokból metabolikus szindrómában szenvedő férfiakba növelte az inzulinérzékenységet [10].

Nem alkoholos steatohepatitises betegek $50 \%$-ában kimutatható a vékonybél bakteriális túlburjánzása, azaz a kontaminált vékonybél szindróma. A bakteriális túlburjánzás összefügg a májelzsírosodás mértékével [11]. A gyomor-bél rendszerből származó lymphocyták a májba vándorolnak és ott hepaticus $\mathrm{CD}^{+}{ }^{+}$és $\mathrm{CD}^{+}{ }^{+} \mathrm{T}$-sejtek aktiválódását váltják ki nem alkoholos zsírmáj egérmodelljében. A gyulladásos aktivitás hozzájárul a májkárosodás progressziójához [12].

Terápiás célpontot jelenthet az intestinalis bélflóra kórlefolyásban betöltött szerepének pontos megismerése. Probiotikumok adása NAFLD-ben a szérumtranszamináz-értékek, a koleszterinszint, a TNF- $\alpha$-koncentráció csökkenését eredményezte, valamint az inzulinérzékenységet növelte [13].

\section{Citokinek}

A citokinek gyulladásos mediátorok, amelyek fontos szerepet játszanak különböző heveny és idült betegségek kórlefolyása során. Számos, a krónikus májbetegségek progressziójában részt vevő citokint vizsgáltak, többek között a tumornekrózis-faktor- $\alpha$-t (TNF- $\alpha$ ), több interleukint (IL-1, IL-6, IL-10, IL-12) és interferont (IFN- $\gamma$ ), valamint a nagy érzékenységú C-reaktív fehérjét (highsensitivity C-reactive protein - hsCRP) [14].

Számos tanulmány a citokinszint és a májbetegségek súlyossága, valamint a fennálló társbetegségek kapcsolatára derített fényt. Az IL-6-, IL-8-, hsCRP- és TNFszintek nagyobbak előrehaladott májkárosodásban. Így a kompenzált és a dekompenzált alkoholos cirrhosis elkülönítésében használható lenne a TNF- $\alpha$ - és az IL-6-szint meghatározása [14-16]. A TNF- $\alpha$, valamint a TGF- $\beta$ (transzformáló növekedési faktor- $\beta$ ) fokozott kifejeződése a májsejtek elhalását, gyulladást eredményez, illetve a csillagsejtek kollagéntermelő myofibroblastokká alakulását, a fibrogenesist fokozza [17].

\section{Kemokinek}

A monocyták, macrophagok, Kupffer-sejtek és májsejtek által termelt kemokin, az interleukin-8 (IL-8) aktiválja a neutrophil granulocytákat. Perifériás neutrophiliát és a máj neutrophil infiltrációját írták le alkoholos májbetegségben. Azon betegeknél, akiknél magasabb IL-8-szintet mértek, nagyobb volt a halálozási arány, mint a kis IL8-szintüeknél [14].

Előrehaladott májkárosodásban gyulladásos faktorok (IL-6, CCL-2, CCL-5, IL-8, osteopontin, semaphorin$7 \mathrm{~A})$, macrophagmarker- (CD-68) és fibrosismarker(TGF- $\beta 1$ ) szintek a májszövettani mintákban magasabbak, mint enyhe májkárosodásban. A kemokinek (osteopontin, semaphorin-7A, IL-8) mRNS-expressziója összefügg a súlyos elzsírosodással (>33\%) [14, 18].

\section{Adipocytokinek}

A fehér zsírszövet által termelt leptin egy 16 kDa méretű hormon vagy citokin. Számos szervben, mint például a májban, a hypothalamusban és a zsírszövetben is megta- 
lálható a receptora (Ob-R). A leptin kötődése receptorához transzkripciós faktorok aktiválódását (Jak-2, Stat-3) eredményezi. A májban lévő aktivált csillagsejtek is képesek a leptin kiválasztására, amellyel saját sejtciklusukat is befolyásolják, mivel a leptin potenciális mitogén [19]. A leptin a diacil-glicerol-acil-transzferáz enzimet aktiválja, amely a toxikus szabad zsírsavakat a kevésbé toxikus trigliceriddé alakítja [17]. A leptin erős transzkripciós stimulust jelent az $\alpha_{1}$ és az $\alpha_{2}$ fibrillumok aktiválódása során, amelyek a fibroticus extracelluláris mátrix fó komponensei. Stimulálja még a TIMP-metallopeptidáz-inhibitor-1 (TIMPl) és a mátrixmetalloproteináz-2 (MMP-2), TIMP-1, TIMP-2 és $\alpha$-SMA de novo mRNS-szintézisét, amelyek központi szerepet játszanak a fibrosis progreszsziójában [19].

Antifibrogén hatású a fehér zsírszövet által termelt, 28 kDa méretű citokin, az adiponektin. Az AdipoR-1 és R-2 receptora a májban expresszálódik. A csökkent adiponektin-szérumszint különböző kóros folyamatokhoz vezet a májban (elzsírosodás, gyulladás, fibrosis). Az adiponektin gátolja a csillagsejtek aktiválódását és proliferációját. Részt vesz továbbá a mátrixlebontásban az MMP1 és TIMP-1 molekuláris arányának megváltoztatása révén. A hypoadiponectinaemia potenciálisan felelős lehet az elhízással szövődött NAFLD progressziójában, emiatt terápiás célpontként is szóba jön [19].

További adipocytokinek (plazminogénaktivátor-inhibitor-1 - PAI-1, rezisztin, apelin, visfatin stb.) szerepe a fibrosis progressziójában még vitatott [19].

\section{Inzulinrezisztencia}

A krónikus májbetegségek és a diabetes mellitus (DM) kapcsolata régóta ismert. A DM előfordulása májbetegek között 20-70\%, a kóreredettől és a májkárosodás súlyosságától függően. Gyakoribb előrehaladott májbetegségben és fóleg alkohol, haemochromatosis, NAFLD vagy HCV-fertőzés okozta cirrhosisban. Az úgynevezett hepatogen diabetesben magasabb a széruminzulinszint, mint a klasszikus, 2-es típusú DM-ben. Ez a jelenség valószínúleg a portoszisztémás söntök és a kóros májmüködés által okozott csökkent májbéli kiválasztás (inzulinclearance $\downarrow$ ) miatt alakul ki [20].

A csökkent inzulinérzékenység a nem alkoholos zsírmájbetegség (NAFLD) progressziójában részt vevó egyik fó mechanizmus [21]. A hyperinsulinaemia indítja be a gének átíródásának fokozását és a de novo lipogenesist a májban. Inzulinérzéketlenségben nagyobb a nem észterifikált zsírsavak felvétele [22]. A májkárosodás következményeként termelődő citokinek a perifériás zsírbontás, illetve a szabadzsírsav-felszabadulás serkentésével az inzulin jelátvivő rendszerét tovább károsítják [17].

\section{Oxidatív stressz}

Számos tanulmány bizonyítja, hogy az idült oxidatív stressz lehet a májbetegségek progressziójának kulcsfo- lyamata. A „két csapás elmélet” (two hit theory) szerint az oxidatív stressz játssza a fószerepet a zsírmáj steatohepatitisszé váló progressziójában. A megnövekedett reaktívoxigéngyök-termelés (ROS) lipidperoxidációt okoz, amelyet gyulladás és a csillagsejtek aktiválódása követ [23]. A mitokondriális ROS-termelődés szerepet játszik az inzulinrezisztencia kialakulásában és az elektrontranszportlánc múködésének csökkenésében. A csökkent múködésû mitokondriumokban így felborul a $\beta$-oxidáció és az oxidatív foszforiláció egyensúlya, amely részlegesen oxidált közti termékek felhalmozódásához vezet, amelyek tovább rontják a folyamatot [24].

A májzsugorban szenvedő betegekben megnövekedett prooxidáns markereket (szérum-malondialdehid MDA) és csökkent antioxidáns (vörösvértest-kataláz, szuperoxid dizmutáz, SOD, vér redukált glutation, GSH) -szintet mértek. A vörösvértestek membránja is változik a redox állapottól függően cirrhosisban szenvedő betegekben, ami összefügg a nagyobb nitrogén-oxidszinttel. A fent említett eltérések összefüggést mutattak a Child-Pugh-pontrendszerrel [25].

A kardiolipin biológiai membránok alkotóeleme. Részt vesz elektrokémiai gradienst fenntartó folyamatokban, amelyek során ATP termelődik. Szerepet játszik a mitokondriumok bioenergetikájában. A mitokondriális kardiolipin oxidációja és kiürülése megváltoztatja a ROSindukált légzésilánc-komplex I., III. és IV. aktivitását [26]. A peroxidált kardiolipin elősegíti a mitokondriális membrán átjárhatóvá válását [27].

A mitokondriális redukált glutation ( $\mathrm{mGSH}$ ) egy eszszenciális antioxidáns, amely szabályozza a reaktívoxigén-gyökök termelődését, és megelőzi a mitokondriális diszfunkciót és a sejthalált. Az mGSH de novo szintetizálódik a citoszolban. Az antioxidáns hatású mGSH csökkent szintje érzékennyé teszi a májsejteket oxidatív stresszel és gyulladásos citokinekkel szemben. Az mGSH kivédi a kardiolipin peroxidált kardiolipinné történő oxidációját [27].

A nemrégen azonosított Sestrin-2 (Sesn-2) egy olyan antioxidáns, amely oxidatív és energetikai stressz során termelődik a sejtekben. Csökkenti a reaktívoxigén-gyökök felhalmozódását, megvédi a sejteket az oxidatív stressztől és befolyásolja a sejtek osztódását és életképességét. A Sesn-2 szerepet játszhat a májkárosodások folyamatában is. Hepatoprotektív tulajdonsága, szerepe a gyulladásos válasz, a metabolikus stressz, a májsejt-regeneráció és karcinogenezis során számos vizsgálat tárgya [28].

A megnövekedett oxidatív stressz aktiválja a sejtes apoptózist, amely során a sérült sejtek eltávolításra kerülnek. A májsejtekben a zavart múködésű mitokondriumok miatt az intrinszik apoptotikus útvonal indul el, amelynek során citokróm c szabadul fel a citoszolban. A mitokondriumon belül az antiapoptotikus Bcl-2 és Bcl-xL fehérjék és a proapoptotikus Bax és Bak fehérjék interakciója indítja el a sejthalált. A májban létrejövő folyamatos sejthalál végül fibrosishoz és cirrhosishoz vezet [29]. 


\section{Mikroelemek szerepe}

A májban lévő reticuloendothelialis rendszer (RES) sejtjeiben vas halmozódik fel NAFLD során. A felhalmozódott vas az oxidatív stressz, az inzulinszignál és a lipidanyagcsere megváltoztatása által befolyásolhatja a betegség progresszióját. A máj RES-sejtjeiben jelen lévô vas a megnövekedett apoptózis és oxidatív stressz jelzője lehet [22].

Számos tanulmány felvetette, hogy a hyperferritinaemia, illetve a májszövettani mintákban kimutatható vasfelhalmozódás előrehaladott NAFLD-betegségben jelentkezik. Kapcsolatot írtak le a vasfelhalmozódás és az inzulinrezisztencia, a NASH talaján kialakult hepatocellularis carcinoma, a transzplantációs várólistán lévő halálozás és a poszttranszplantációs halálozás között [30].

A vashoz hasonlóan a réz is számos, alapvető biológiai funkcióban vesz részt. A nem alkoholos zsírmáj kórlefolyásában szerepet játszó egyik kulcsesemény az oxidatív stressz. A szabad gyökök elleni védekezés egyik vezető enzime a $\mathrm{Cu} / \mathrm{Zn}$ szuperoxid dizmutáz (SOD). A rendelkezésre álló réz mennyiségétől függ a SOD múködése. Feltételezhető a szérumban mérhető réz kapcsolata a betegség előrehaladásával. Magas fruktóztartalmú étkezés csökkenti a réz felszívódását a patkóbélből. A csökkent rézszint kapcsolatban áll a NAFLD kórlefolyásában szerepet játszó mitokondriális diszfunkcióval és a lipidperoxidációval. Terápiás célpontot jelenthet a jövőben a diéta szempontjából a rézpótlás, valamint a vasfelhalmozódás és a többletkalória-bevitel csökkentése [31].

\section{Mitokondriális stressz}

A nem alkoholos zsírmájbetegség alapja a lipidfelhalmozódás a hepatocytákban. A májsejtekben lévő mitokondriumok vezénylik a lipidanyagcsere összetett rendszerét. A mitokondriális diszfunkció egyik feltételezett oka a ROS felszaporodása a betegség során. A ROS károsítja az elektrontranszportlánc- (ETC-) komplexeket, és a mitokondriális DNS-ben mutációkat hoz létre. Emellett reaktívnitrogén-gyökök (RNS) is károsítják a légzési lán$\cot [24,32]$.

A károsodott mitokondriumokban a zsírsavak bétaoxidációjának és oxidatív foszforilációjának egyensúlya felborul és részlegesen oxidált közti termékek felhalmozódásához vezet. Ez a folyamat hozzájárul az inzulinrezisztencia és a nem alkoholos zsírmáj kialakulásához [24].

\section{Sejthalál}

A hepaticus sejthalál számos mechanizmus során mehet végbe. Oka lehet a fent részletezett oxidatív stressz és a mitokondriális diszfunkció. Több jelátviteli úton zajlik, amelynek során halálreceptor által közvetített kaszkádokon keresztül megy végbe a folyamat [33].
A hepatitis A- és E-vírus, a cytomegalovirus, az Epstein-Barr-vírus fóleg heveny májkárosodást idéz elő, amelyet elsősorban necrosis jellemez. Az idült májbetegséget létrehozó hepatitis B- és C-vírus-fertőzés során az apoptózis a jellemző sejtkárosodás [33]. A HCV-fertőzött májsejtekben TNF- $\alpha$, TGF- $\beta$, IFN- $\gamma$, interleukin- 10 (IL-10), IL-12, IL-22, CCL-3, CCL-4, CXCR-3 ligand, IP-10 és CCR-5 ligand termelődik. Ezek a citokinek és kemokinek a sejthalált különböző útvonalakon keresztül indíthatják el [33-35]. HBV-fertőzés során TNF- $\alpha$-, TNFRl - és Fas-expresszió következik be. A tumornekrózis-faktor által beindított apoptotikus útvonal (TRAIL) a kaszpáz-8 aktiválódásán keresztül vezet a sejthalálhoz $[33,36]$.

Alkoholos májkárosodás során az egyik fó mechanizmus a reaktívoxigéngyök-termelődés a CYP3El-indukció miatt. Az alkoholfogyasztás a Kupffer-sejtek által termelt citokin felszabadulásához (TNF- $\alpha$, IL-8) vezet, az endotoxin receptorok (TLR-4) és intracelluláris jelátviteli molekulák (kaszpáz-3) kifejeződését fokozza. A folyamat eredményeként sejthalál következik be [33].

Nem alkoholos zsírmájbetegségben a kóros inzulinválasz és lipidanyagcsere, az idült gyulladás és oxidatív stressz felelős a sejthalál bekövetkezéséért. A betegség során keletkező toxikus zsírsavak a lizoszomális apoptotikus útvonalat indítják el, amelynek során a TNF- $\alpha$, a Fas és a TRAIL-receptor expresszióját írták le biopsziás mintákban [37]. A zsírsavak a JNK-útvonalon keresztül is befolyásolják az intrinszik apoptotikus útvonalat, amelynek következtében mitokondriális permeabilitásfokozódás, citokróm c-felszabadulás és kaszpázaktiválódás jön létre [38].

\section{A génállomány eltérései}

A krónikus májbetegségek progresszióját genetikai tényezők is befolyásolják. Különböző génpolimorfizmusok állnak a vizsgálatok középpontjában. GWAS tanulmányok szerint hepatitis C-vírus-fertőzésben a 19-es kromoszóma IL-28B locusán található genetikai polimorfizmus összefüggést mutat a fibrosis és a gyulladásos aktivitás mértékével. A D-vitamin-receptor genetikai eltérései a fibrosis előrehaladását befolyásolják. A patatinszerú foszfolipáz-3 (patatin-like phospholipase 3 PNPLA-3) genetikai polimorfizmusa összefüggést mutatott a nagyobb cirrhosiskockázattal és a rosszabb terápiás válasszal $\mathrm{HCV}$-fertőzésben [39].

A PNPLA-3 polimorfizmusának szerepét kutatják nem alkoholos zsírmájbetegségben. A PNPLA3-148MM genotípusúakban kisebb trigliceridszinteket mértek és ritkább volt a metabolikus szindróma előfordulása [40]. A PNPLA-3 Il48M (rs738409) -hordozás nagyobb kockázatot jelent a steatosissal, fibrosissal és gyulladással jellemzett progresszív májbetegség kialakulására. Ezen személyeknél nagyobb valószínúséggel alakul ki inzulinrezisztencia és 2-es típusú cukorbetegség [41]. Az MTTP 297H (mikroszomális triglicerid transz- 
fer protein) polimorfizmusa az NAFLD és az inzulinrezisztencia kialakulására magasabb kockázatot jelent [42].

A TM6SF2-hordozás összefügg a progresszív májbetegségekkel és a metabolikus szindróma kialakulásával [43]. Az NAFLD-ben kimutatott további genetikai eltérések a glukokinázregulátor (GCKR, SNP rs780094), a lipin-1 (LPIN-1), a FATP-5, az UCP-2 és a lizofoszfolipázszerü-1 (LYPLAL-1, SNP rs12137855) -polimorfizmusok [44].

\section{Epigenetikai szabályozás}

A DNS-metiláció, a hisztoneltérések és a mikro-RNS-ek szerepe a legtöbbet vizsgált epigenetikai módosulások. A táplálkozás, különböző gyógyszerek, a stressz és egyéb környezeti hatások befolyásolják ezeket a folyamatokat. Az epigenetikai hatások szerepet játszanak a lipidanyagcserében, a mitokondriális diszfunkcióban, a sejthalál, az oxidatív stressz és a gyulladásos válasz folyamatában. Részt vesznek a nem alkoholos zsírmájbetegség progressziójának fenntartásában. Az epigenetikai faktorok pontos megismerése megelőzô és terápiás szereppel bírhat a jövőben [45].

A DNS-metiláció a legismertebb epigenetikai folyamat. A DNS-metiltranszferázok (DNMT) alakítják a citozint 5-metil-citozinná ott, ahol fóleg citozin-guanin dinukleotidok találhatók. Ezeken a szakaszokon géncsendesítés, azaz a gének átíródását gátló tényezők kódolása történik [46]. A DNS-metiláció az S-adenozilmetionin (SAM) mennyiségétől függ. A különböző ételek metilcsoportot adó (folsav, kolin, betain) képessége kapcsolatban áll a SAM-szintézissel [45].

A folsav katalizáló szerepet tölt be a metilcsoportok szállításában. A folsavelégtelenség kapcsolatban áll a májban történő trigliceridfelhalmozódással nem alkoholos zsírmájbetegségben és steatohepatitisben. A folsavbevitel megváltoztatja a lipidanyagcserében és a metabolikus szindrómában szerepet játszó gének kifejeződését [45, 46].

A hisztonmódosulásokban szerepet játszó reakciók az acetiláció, a metiláció, a foszforiláció és az ubiquitináció. A hisztonacetiláció szerepe jelentős nem alkoholos zsírmájbetegségben [45]. Egér-NAFLD-modellekben a szabad zsírsavak serkentik az ATP-függő kromatin remodelling fehérje Brgl-aktivitását, amely a steatosis, a gyulladásos aktivitás és a kötőszövetes átépülés folyamatában játszik döntő szerepet $[47,48]$.

A mikro-RNS-ek egyszálú, 18-24 nukleotidhosszúságú, nem kódoló RNS-ek. Gének kifejeződését szabályozzák poszttranszkripcionálisan. A csillagsejtek aktiválódásában szerepet játszanak a miR-29, a miR-146 és a miR-16 mikro-RNS-ek [49]. HCV-fertőzésben a miR122 részt vesz a vírus stabilitásában és propagációjában [50-52]. Számos vizsgált mikro-RNS közül a miR-21, a miR-122 és a miR-223 kapcsolatát írták le a fibrosis mértékével krónikus HBV-fertőzésben [53]. Nem alkoholos zsírmájbetegségben a miR-122, a miR-451, valamint a
miR-27 csökkent kifejeződését írták le [54]. NASH-ben a miR-197 és miR-99 szintje korrelált a fibrosis mértékével [45].

\section{Következtetések}

Kulcsfontosságú a krónikus májbetegségek progressziójában szerepet játszó tényezők ismerete. A progresszió folyamata összetett, nem pontosan ismert, számos útvonalon megy végbe.

Több sejtes elem vesz részt a kórlefolyásban. Szerepet játszanak a gyulladás, a zsírfelhalmozódás és kötőszövetes átépülés folyamatában. Az általuk termelt citokinek, kemokinek, gyulladásos mediátorok tovább rontják a kialakult károsodást. Fontos tényező továbbá az oxidatív stressz által katalizált mitokondriális kóros múködés és a következményes májsejtelhalás. A szénhidrát-anyagcsere eltérései és a mikroelemek koncentrációja is befolyásolhatják a betegség előrehaladását. Genetikai és epigenetikai vonatkozások is részt vesznek a krónikus májbetegségek lefolyásának szabályozásában.

A kórlefolyás pontos megismerése befolyásolhatja a kórisme felállítását, a kezelés megkezdésének időpontját, a hosszú távú prognózist, a májtranszplantáció időpontjának megítélését, és fơként új terápiás lehetőségek kifejlesztését. Igény van nem invazív diagnosztikus módszerek fejlesztésére, amelyek segítségével a betegség előrehaladása monitorozható. A progresszióban részt vevő több tényező is szerepel nem invazív diagnosztikus módszerekben, pontrendszerekben.

Az életmódváltásnak, az alkohol elhagyásának, az antioxidánsterápiának, valamint a testsúlycsökkenés progressziót befolyásoló hatásának vizsgálata kiemelt fontosságú lenne a betegek életminősége szempontjából.

Anyagi támogatás: A közlemény megírása anyagi támogatásban nem részesült.

Szerzôi munkamegosztás: H. K.: A téma felvetése. E. A., L. G., S. A., B. A., H. K.: A kézirat megszövegezése. A cikk végleges változatát valamennyi szerző elolvasta és jóváhagyta.

Érdekeltségek: A szerzőknek nincsenek érdekeltségeik.

\section{Irodalom}

[1] Crosas-Molist, E., Fabregat, I.: Role of NADPH oxidases in the redox biology of liver fibrosis. Redox Biol., 2015, 6, 106-111.

[2] Hagymási, K., Lengyel, G.: Non-alcoholic steatosis/steatohepatitis - 2010. [Nem alkoholos steatosis/steatohepatitis - 2010.] Orv. Hetil., 2010, 151(47), 1940-1945. [Hungarian]

[3] Attallah, A. M., Omran, M. M., Farid, K., et al.: Development of a novel score for liver fibrosis staging and comparison with eight simple laboratory scores in large numbers of HCV-monoinfected patients. Clin. Chim. Acta, 2012, 413(21-22), 1725-1730. 
[4] Forbes, S. J., Russo, F. P., Rey, V., et al.: A significant proportion of myofibroblasts are of bone marrow origin in human liver fibrosis. Gastroenterology, 2004, 126(4), 955-963.

[5] Elpek, G. Ö.: Cellular and molecular mechanisms in the pathogenesis of liver fibrosis: An update. World J. Gastroenterol., 2014, 20(23), 7260-7276.

[6] Almeda-Valdes, P., Aguilar Olivos, N. E., Barranco-Fragoso, B., et al.: The role of dendritic cells in fibrosis progression in nonalcoholic fatty liver disease. Biomed. Res. Int., 2015, 2015, 768071.

[7] Kmieć, Z.: Cooperation of liver cells in health and disease. Adv. Anat. Embryol. Cell Biol., 2001, 161, III-XIII, 1-151.

[8] Gressner, O. A., Weiskirchen, R., Gressner, A. M.: Biomarkers of liver fibrosis: clinical translation of molecular pathogenesis or based on liver-dependent malfunction tests. Clin. Chim. Acta, 2007, 381(2), 107-113.

[9] Abdul-Hai, A., Abdallah, A., Malnick, S. D.: Influence of gut bacteria on development and progression of non-alcoholic fatty liver disease. World J. Hepatol., 2015, 7(12), 1679-1684.

[10] Vrieze, A., Van Nood, E., Holleman, F., et al.: Transfer of intestinal microbiota from lean donors increases insulin sensitivity in individuals with metabolic syndrome. Gastroenterology, 2012, 143(4), 913-916.e7.

[11] Sabaté, J. M., Jouët, P., Harnois, F., et al.: High prevalence of small intestinal bacterial overgrowth in patients with morbid obesity: a contributor to severe hepatic steatosis. Obes. Surg., 2008, 18(4), 371-377

[12] Hu, Y., Zhang, H., Li, J., et al.: Gut-derived lymphocyte recruitment to liver and induce liver injury in non-alcoholic fatty liver disease mouse model. J. Gastroenterol. Hepatol., 2015 Oct 2. doi: 10.1111/jgh.13183. [Epub ahead of print]

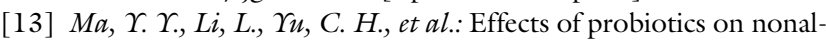
coholic fatty liver disease: a meta-analysis. World J. Gastroenterol., 2013, 19(40), 6911-6918.

[14] Neuman, M. G., Maor, Y., Nanau, R. M., et al.: Alcoholic liver disease: role of cytokines. Biomolecules, 2015, 5(3), 2023-2034.

[15] Mortensen, C., Andersen, O., Krag, A., et al.: High-sensitivity $\mathrm{C}$-reactive protein levels predict survival and are related to haemodynamics in alcoholic cirrhosis. Eur. J. Gastroenterol. Hepatol., 2012, 24(6), 619-626.

[16] Ishikawa, M., Uemura, M., Matsuyama, T., et al.: Potential role of enhanced cytokinemia and plasma inhibitor on the decreased activity of plasma ADAMTS13 in patients with alcoholic hepatitis: relationship to endotoxemia. Alcohol. Clin. Exp. Res., 2010, 34(Suppl. 1), S25-S33.

[17] Hagymási, K., Lengyel, G., Tulassay, Zs.: Non-alcoholic fatty liver in 2013. [A nem alkoholos zsírmáj betegségről 2013-ban.] Magyar Belorv. Arch., 2013, 66(4), 185-191. [Hungarian]

[18] Morales-Ibanez, O., Dominguez, M., Ki, S. H., et al.: Human and experimental evidence supporting a role for osteopontin in alcoholic hepatitis. Hepatology, 2013, 58(5), 1742-1756.

[19] Saxena, N. K., Anania, F. A.: Adipocytokines and hepatic fibrosis. Trends Endocrinol. Metab., 2015, 26(3), 153-161.

[20] Grancini, V., Trombetta, M., Lunati, M. E., et al.: Contribution of beta-cell dysfunction and insulin resistance to cirrhosis-associated diabetes: role of severity of liver disease. J. Hepatol., 2015, 63(6), 1484-1490.

[21] Milic, S., Mikolasevic, I., Krznaric-Zrnic, I., et al.: Nonalcoholic steatohepatitis: emerging targeted therapies to optimize treatment options. Drug Des. Devel. Ther., 2015, 9, 4835-4845.

[22] Onyekwere, C. A., Ogbera, A. O., Samaila, A. A., et al.: Nonalcoholic fatty liver disease: synopsis of current developments. Niger. J. Clin. Pract., 2015, 18(6), 703-712.

[23] Del Ben, M., Polimeni, L., Carnevale, R., et al.: NOX2-generated oxidative stress is associated with severity of ultrasound liver steatosis in patients with non-alcoholic fatty liver disease. BMC Gastroenterol., 2014, 14, 81
[24] Gusdon, A. M., Song, K. X., Qu, S.: Nonalcoholic fatty liver disease: pathogenesis and therapeutics from a mitochondria-centric perspective. Oxid. Med. Cell. Longev., 2014, 2014, 637027.

[25] Cichoż-Lach, H., Michalak, A.: Oxidative stress as a crucial factor in liver diseases. World J. Gastroenterol., 2014, 20(25), 80828091.

[26] Paradies, G., Paradies, V., Ruggiero, F. M., et al.: Oxidative stress, cardiolipin and mitochondrial dysfunction in nonalcoholic fatty liver disease. World J. Gastroenterol., 2014, 20(39), 1420514218 .

[27] Arguello, G., Balboa, E., Arrese, M., et al.: Recent insights on the role of cholesterol in non-alcoholic fatty liver disease. Biochim. Biophys. Acta, 2015, 1852(9), 1765-1778.

[28] Kim, K. M., Yang, J. H., Shin, S. M., et al.: Sestrin2: a promising therapeutic target for liver diseases. Biol. Pharm. Bull., 2015, 38(7), 966-970.

[29] Auger, C., Alhasawi, A., Contavadoo, M., et al.: Dysfunctional mitochondrial bioenergetics and the pathogenesis of hepatic disorders. Front. Cell Dev. Biol., 2015, 3, 40.

[30] Feldman, A., Aigner, E., Weghuber, D., et al.: The potential role of iron and copper in pediatric obesity and nonalcoholic fatty liver disease. Biomed. Res. Int., 2015, 2015, 287401.

[31] Aigner, E., Weiss, G., Datz, C.: Dysregulation of iron and copper homeostasis in nonalcoholic fatty liver. World J. Hepatol., 2015, 7(2), 177-188

[32] Carreras, M. C., Franco, M. C., Peralta, J. G., et al.: Nitric oxide, complex I, and the modulation of mitochondrial reactive species in biology and disease. Mol. Aspects Med., 2004, 25(1-2), 125139.

[33] Wang, K.: Molecular mechanisms of hepatic apoptosis. Cell Death Dis., 2014, 5, e996.

[34] Apolinario, A., Majano, P. L., Alvarez-Perez, E., et al.: Increased expression of $\mathrm{T}$ cell chemokines and their receptors in chronic hepatitis C: relationship with the histological activity of liver disease. Am. J. Gastroenterol., 2002, 97(11), 2861-2870.

[35] Barrett, S., Collins, M., Kenny, C., et al.: Polymorphisms in tumour necrosis factor-alpha, transforming growth factor-beta, interleukin-10, interleukin-6, interferon-gamma, and outcome of hepatitis C virus infection. J. Med. Virol., 2003, 7l(2), 212218.

[36] Feitelson, M. A., Reis, H. M., Tufan, N. L., et al.: Putative roles of hepatitis $\mathrm{B} \times$ antigen in the pathogenesis of chronic liver disease. Cancer Lett., 2009, 286(1), 69-79.

[37] Malhi, H., Barreyro, F. J., Isomoto, $H$., et al.: Free fatty acids sensitise hepatocytes to TRAIL mediated cytotoxicity. Gut, 2007, 56(8), 1124-1131.

[38] Malhi, H., Bronk, S. F., Werneburg, N. W., et al.: Free fatty acids induce JNK-dependent hepatocyte lipoapoptosis. J. Biol. Chem., 2006, 281(17), 12093-12101.

[39] Rau, M., Baur, K., Geier, A.: Host genetic variants in the pathogenesis of hepatitis C. Viruses, 2012, 4(12), 3281-3302.

[40] Del Ben, M., Polimeni, L., Brancorsini, M., et al.: Non-alcoholic fatty liver disease, metabolic syndrome and patatin-like phospholipase domain-containing protein 3 gene variants. Eur. J. Intern. Med., 2014, 25(6), 566-570.

[41] Firneisz, G.: Non-alcoholic fatty liver disease and type 2 diabetes mellitus: the liver disease of our age? World J. Gastroenterol., 2014, 20(27), 9072-9089.

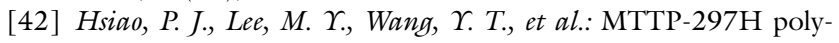
morphism reduced serum cholesterol but increased risk of nonalcoholic fatty liver disease-a cross-sectional study. BMC Med. Genet., 2015, 16, 93.

[43] Anstee, Q. M., Day, C. P.: The genetics of nonalcoholic fatty liver disease: Spotlight on PNPLA3 and TM6SF2. Semin. Liver Dis., $2015,35(3), 270-290$

[44] Dongiovanni, P., Romeo, S., Valenti, L.: Genetic factors in the pathogenesis of nonalcoholic fatty liver and steatohepatitis. Biomed. Res. Int., 2015, 2015, 460190. 
[45] Sun, C., Fan, J. G., Qiao, L.: Potential epigenetic mechanism in non-alcoholic fatty liver disease. Int. J. Mol. Sci., 2015, 16(3), 5161-5179.

[46] Page, A., Mann, D. A.: Epigenetic regulation of liver fibrosis. Clin. Res. Hepatol. Gastroenterol., 2015, 39(Suppl. 1), S64S68.

[47] Da Silva, R. P., Kelly, K. B., Al Rajabi, A., et al.: Novel insights on interactions between folate and lipid metabolism. Biofactors, $2014,40(3), 277-283$.

[48] Tian, W., Xu, H., Fang, F., et al.: Brahma-related gene 1 bridges epigenetic regulation of proinflammatory cytokine production to steatohepatitis in mice. Hepatology, 2013, 58(2), 576-588.

[49] Lambrecht, J., Mannaerts, I., van Grunsven, L. A.: The role of miRNAs in stress-responsive hepatic stellate cells during liver fibrosis. Front. Physiol., 2015, 6, 209.

[50] $L i, G$., Cai, G., $L i, D$., et al.: MicroRNAs and liver disease: viral hepatitis, liver fibrosis and hepatocellular carcinoma. Postgrad. Med. J., 2014, 90(1060), 106-112.

[51] Lendvai, G., Jármay, K., Karácsony, G., et al.: Elevated miR-33a and miR-224 in steatotic chronic hepatitis $\mathrm{C}$ liver biopsies. World J. Gastroenterol., 2014, 20(41), 15343-15350.
[52] Lendvai, G., Kiss, A., Kovalszky, I., et al.: Alterations in microRNA expression patterns in liver diseases. [Eltérések a májbetegségek mikro-RNS-expresszió mintázatában.] Orv. Hetil., 2010, 151(45), 1843-1853.

[53] Zhang, Q., Xu, M., Qu, Ү., et al.: Analysis of the differential expression of circulating microRNAs during the progression of hepatic fibrosis in patients with chronic hepatitis B virus infection. Mol. Med. Rep., 2015, 12(4), 5647-5654.

[54] Halász, T., Horváth, G., Pár, G., et al.: miR-122 negatively correlates with liver fibrosis as detected by histology and FibroScan. World J. Gastroenterol., 2015, 21(25), 7814-7823.

(Hagymási Krisztina dr., Budapest, Szentkirályi u. 46., 1088 e-mail: hagymasi.krisztina@med.semmelweis-univ.hu)

A Semmelweis Egyetem Általános Orvostudományi Kara örömmel tesz eleget annak a hagyománynak, hogy volt diákjait jubileumi díszoklevéllel tünteti ki.

Kérjük ezért azokat az orvosokat, akik diplomájukat az egyetem jogelődjénél, a BUDAPESTI KIRÁLYI MAGYAR PÁZMÁNY PÉTER TUDOMÁNYEGYETEMEN, a PÁZMÁNY PÉTER TUDOMÁNYEGYETEMEN, illetve a BUDAPESTI ORVOSTUDOMÁNYI EGYETEMEN

1941-ben

1946-ban

1951-ben

1956-ban

1966-ban

szerezték meg, és szakterületükön legalább 30 évig dolgoztak, nyújtsák be kérelmüket a platina, rubin, vas, gyémánt, illetve arany díszoklevél elnyerése érdekében lehetőleg 2016. április 30-ig, a következő címre, az alábbi jelentkezési lapon.

A jubileumi díszoklevelek átadására elöreláthatóan októberben kerül sor.

A pontos időpontról meghívó útján küldünk értesítést.

\section{Semmelweis Egyetem Általános - Orvostudományi Kar \\ OM azonosító: FI62576 \\ Dékáni Hivatal \\ 1085 Budapest, Üllöi út 26. vagy 1428 Budapest Pf. 2.}

\section{JELENTKEZÉSI LAP}

arany, gyémánt, vas, rubin és platina díszoklevélhez

NÉV

(névváltoztatás feltüntetésével)

Születési idő:

Diploma kelte:

Lakcím:

Telefonszám:

E-mail cím:

Utolsó munkahely:

Rövid szakmai önéletrajz:

Dátum: 